\title{
Editorial on EAIT 2014-1
}

\author{
Arthur Tatnall
}

Published online: 12 January 2014

(C) Springer Science+Business Media New York 2014

The first issue of EAIT for 2014 has 15 articles investigating the use of computers and ICT in education. Ranging from educational issues with the use of Facebook, through online learning, mLearning and problem-based learning to learning packages involving computer-based training and for strategic decision-making by NATO staff, this issue again illustrates the wide range of interesting topics in this field.

The first article is by Jason Hutchens from the University of North Carolina and Timothy Hayes from North Georgia College and State University, USA and is titled: In your Facebook: Examining Facebook Usage as Misbehavior on Perceived Teacher Credibility. The article notes that teachers sometimes do things that can negatively impact their own credibility in classroom settings and that one way they can maintain credibility among students is by keeping a veil between their personal and professional personas. The article describes a study to examine whether or not educator usage of Facebook had any impact on student perceptions of teacher credibility,

The next article also deals with Facebook. Tapping the educational potential of Facebook: Guidelines for use in higher education by Rex Wang from Adfaith Management Consulting Inc., Beijing, China, Phil Scown, Cathy Urquhart and Julie Hardman from Manchester Metropolitan University, UK. It notes that Facebook is a frequently used Computer Mediated Environment for students and others used to build social connections. Its widespread use makes it appropriate for consideration as an educational tool. They note, however, that it is one that does not yet have clear guidelines for use. Their article describes a study conducted at the University of Auckland and at Manchester Metropolitan University on how students use Facebook and its impact on their social and academic lives.

Ugur Kale from West Virginia University, USA and Debbie Goh from Nanyang Technological University, Singapore next write about Teaching style, ICT experience and teachers' attitudes toward teaching with Web 2.0. They write that emphasis on 21st Century skills development has increased expectations on teachers to take advantages of emerging technologies to support student learning. Their study aimed to identify K12 teachers' attitudes toward the use of Web 2.0 technologies in their teaching. Overall, their findings indicate that while teachers are fairly proficient in their computer and

\footnotetext{
A. Tatnall $(\bowtie)$

Victoria University, PO Box 14428, Melbourne 8001, Australia

e-mail: Arthur.Tatnall@vu.edu.au
} 
internet skills and have fairly high computer self-efficacy, their workload and a structured and standardised curriculum were inhibitors of Web 2.0 adoption.

Continuing the discussion of online technologies Efthimios Tambouris, Maria Zotou and Konstantinos Tarabanis from the University of Macedonia, Greece write: Towards designing cognitively-enriched project-oriented courses within a blended problembased learning context. They note that traditional education seems to gradually and moderately make way for self-directed and student-centred learning strategies that will efficiently enable students to reach their full potentials and will prepare them for their upcoming professional careers. Problem-Based Learning (PBL) is a strategy that enables active participation by shifting the focus from the delivery of knowledge to its creation by the students, in their endeavour to implement problem-based projects. Their article investigates the incorporation of cognitive technologies using blended strategies in project-oriented courses.

Video databases: An emerging tool in business education by Gregory MacKinnon and Conor Vibert from Acadia University, Canada, describe an action research study that was designed to determine the most suitable assignment work to associate with the database in a Business Strategy course and to analyse the way that the nature of learning was impacted by this technology intervention.

mLearning: Anytime, anywhere learning transcending the boundaries of the educational box by Micah Shippee from Syracuse University and Jared Keengwe from the University of North Dakota, USA, points out that the clear societal value of mobile technology as a productivity tool for engagement, creation, and collaboration has generated a new need for education to revisit existing teaching paradigms constrained by physical walls and time. Their article explores the factors that national, state and local educational organizations must understand to make steps toward successful integration of mLearning technology.

Access, use and perceptions of teachers and students towards mobile phones as a tool for teaching and learning in Tanzania by Ayoub Kafyulilo from University College of Education, Dar es salaam, Tanzania explores the access, use and perceptions of teachers and students towards mobile phones as a tool for facilitating teaching and learning beyond the classroom walls. The findings showed that all in-service teachers, college instructors and pre-service teachers, and $60 \%$ of school students, owned or had access to mobile phones. Students, pre-service teachers and college instructors were in favour of the use of mobile phones for learning, but most in-service teachers were against it. This suggests the need for a professional development programme to help development of a positive attitude towards mobile phones use in teaching and learning.

Following is an article by Eleni Voyiatzaki and Nikolaos Avouris from the University of Patras, Greece, titled: Support for the teacher in technology-enhanced collaborative classroom. Their article presents a study on the role of the teacher in computersupported class group activities in which the students are engaged in group activities through networked computers. The article discusses various teacher tools that support this role.

Using technology pedagogical content knowledge development to enhance learning outcomes is an article by Douglas Agyei from the University of Cape Coast, Ghana and Jared Keengwe from the University of North Dakota, USA. This article describes an intervention in which pre-service teachers developed their TPACK (Technological Pedagogical Content Knowledge framework) through multiple data sources. The 
learning outcome measures provide specific information and concrete representation of what pre-service teachers can actually do with technology in their TPACK development and the findings suggested multiple concerns about self-reported measures that are discussed in the framework of the TPACK instrument.

The next article is a quite technical description of a model of computer adaptive testing and grade formation. Titled: CAT model with personalized algorithm for evaluation of estimated student knowledge, it was written by Svetlana Andjelic from the Information Technology School and Zoran Cekerevac from 'Union' University Belgrade, Serbia. This article presents the original model of the computer adaptive testing and grade formation, the base of which is a personalized algorithm for selection of questions depending on the accuracy of the answer to the previous question. The research method and some results of the testing of the hypotheses as well as authors' conclusions about CAT as a tool for evaluation of students are also presented.

Computer-based training (CBT) is the basis of an article by Ayse Kok, from Bogazici University, Turkey titled: A conceptual design model for CBT development: A NATO case study. The article points out that CBT can benefit from modern multimedia tools combined with network capabilities. The article focuses on CBT development to improve strategic decision-making with regard to air command and control system for NATO staff in a virtual environment.

Maria Limniou and Michael Smith from the University of Manchester then write on: The role of feedback in e-assessments for engineering education. The aim of their reported investigation was to compare two differently designed e-assessments which supported the same engineering courses for two academic years. The first group of students had the opportunity to timely receive grades along with the correct answers when they submitted the e-assessments on-line. The second group of students had the opportunity to receive feedback each on their own individual responses having unlimited attempts to participate in the e-assessments designed by PhD students. The study found that the addition of individual feedback and the unlimited attempts increased the second group's performance in comparison to the first group of students.

Establishing documentary production support for 21 st century campuses is by Elizabeth Davison and Thomas Hansell from Appalachian State University, USA. They write that as a response to the growing trend of academic assignments that involve some type of video production, campuses need to provide instructional as well as technical support for such projects. Their paper presents a model for offering documentary services to entire campus communities including technology, technique, and pedagogical considerations that lead to educational film productions with strong academic content and integrity.

A theoretical framework and model towards media-rich social presence design practices is a contribution from Susan Elwood (Texas A \& M University-Corpus Christi), Karen McCaleb (University-Corpus Christi), Jared Keengwe (University of North Dakota) and Mary Fernandez (Texas A \& M University-Corpus Christi), USA. In their article they note that educators are seeing rapid developments in online instruction with regard not only to available technologies, but also in design and teaching practices. The article touches upon some historical perspectives of social presence and proposes a theoretical framework and design guide towards media-rich social presence practices for future research. 
The final article: The history of UTAUT model and its impact on ICT acceptance and usage by academicians was written by N. D. Oye, N. A.Iahad and N. Ab.Rahim from Universiti Teknologi Malaysia. The article begins with a review of the history of the technology acceptance model from the Theory of Reasoned Action (TRA) to the Unified Theory of Acceptance and Use of Technology (UTAUT) with the expected contribution of bringing to light the current development stage of technology acceptance models. Their research suggests that university academic staff will intend to use ICT if they believe it will improve their job performance and be easy to use. Facilitating conditions such as appropriate hardware, software, training and support should be put in place by management.

Arthur Tatnall

Editor-in-Chief 